\title{
De houding van de Amerikaanse Joint ten opzichte van de orthodoxie : de Antwerpse casus
}

\section{Veerle Vanden Daelen}

\section{(2) OpenEdition}

\section{Journals}

Édition électronique

URL : http://journals.openedition.org/cmc/983

DOI : $10.4000 / \mathrm{cmc} .983$

ISSN : 2684-3080

\section{Éditeur}

Fondation de la Mémoire Contemporaine

\section{Édition imprimée}

Date de publication : 1 janvier 2005

Pagination : 205-238

ISSN : 1377-1256

\section{Référence électronique}

Veerle Vanden Daelen, « De houding van de Amerikaanse Joint ten opzichte van de orthodoxie : de Antwerpse casus », Les Cahiers de la Mémoire Contemporaine [Online], 6 | 2005, Online op 01 novembre 2020, geraadpleegd op 14 novembre 2020. URL : http://journals.openedition.org/cmc/983 ; DOI : https://doi.org/10.4000/cmc.983 


\title{
De houding van de Amerikaanse Joint ten opzichte van de orthodoxie : de Antwerpse casus
}

\author{
Veerle Vanden Daelen
}

Het American Jewish Joint Distribution Committee (AJJDC, Joint) werd in 1914 opgericht als een neutrale organisatie voor hulp aan joden in nood. Deze neutraliteit werd intern en extern vooral gewikt en gewogen als het ging over de Joint's standpunt ten opzichte van het zionisme. Veel minder aandacht was er voor haar houding ten opzichte van de orthodoxie. Over het algemeen lijkt de Joint de orthodoxie steeds gesteund te hebben. Rabbijnen en orthodoxe en chassidische groepen werden met eerbied benaderd ${ }^{1}$. Wij willen dit graag toetsen aan de specifiek Antwerpse situatie. In dit artikel bespreken we de steun van de Joint aan de orthodoxe en chassidische groepen in Antwerpen na de oorlog. We focussen hierbij speciaal op de opvang van joodse weeskinderen en het joodse onderwijssysteem en raken dan nog enkele andere aspecten kort aan. Vanuit deze concrete Antwerpse casus willen we toetsen in hoeverre de Joint inderdaad orthodoxe groepen steun verleende.

\section{Twee beslissingsniveaus}

Om de houding van de Joint weer te geven moeten we minstens met twee niveaus rekening houden : de houding van het hoofdkantoor van de Joint in New York en deze van de Joint-vertegenwoordigers voor België, die nauw samenwerkten met de Brusselse Aide aux Israélites Victimes de la Guerre (AIVG), de organisatie bij wie de Joint haar middelen voor België na de oorlog centraliseerde. We bespreken eerst de onderhandelingen die in de VS plaatsvonden tussen de Joint en de orthodoxe organisaties ginds.

1 Y. Bauer, Out of the Ashes : the Impact of American Jews on Post-holocaust European Jewry, Oxford-New York, 1989, p. 213. 


\section{De besprekingen in de VS}

De Joint was in Amerika onlosmakelijk verbonden met het United Jewish Appeal (UJA), dat in heel Amerika omhalingen deed voor joodse onderlinge hulp. Het door het UJA verzamelde geld werd telkens verdeeld over de verschillende hulporganisaties in Amerika, waarvan de Joint zonder enige twijfel de grootste was. De Joint wilde de geldomhalingen in Amerika zoveel mogelijk centraliseren rond het UJA. Deze meende met één centrale omhaling meer middelen te verzamelen en deze dan ook veel efficiënter te kunnen verdelen naargelang de specifieke noden. Bovendien, en dat speelde zeker mee, zouden haar eigen werkingsmiddelen hierdoor verhogen. Niet iedereen in Amerika was echter overtuigd van dit centraal collectesysteem en zeker orthodoxe joden speelden op zeker door het oprichten en onderhouden van aparte hulpcircuits om specifieke noden van orthodoxe joden te kunnen ledigen.

Eén van deze organisaties was de in november 1939 door de orthodoxe Agudas Harabanim - Union of Orthodox Rabbis of the USA and Canada (Union of Orthodox Rabbis) opgerichte Vaad Hahatzala. Voluit heette de organisatie Vaad Hahazala, Emergency Committee for WarTorn Yeshivot. Het was de orthodoxe variant van de Joint. Dergelijke organisatie was volgens orthodox Amerika een noodzaak. Het hoofdzakelijk uit Duits joodse "aristocraten" samengestelde Joint-bestuur kon volgens hun nauwelijks het niveau halen in begrip en appreciatie voor Thora-studie dat de in Oost-Europa geboren en opgegroeide leiders van de Union of Orthodox Rabbis zouden respecteren ${ }^{2}$. Daarom besloten ze ook om zelfstandig te ageren. Vaad Hahatzala's belangrijkste doel was " to save the bearers of tradition and Jewish scholarschip, for without them there would be no Jewry, no future for the Jewish people ${ }^{3}$. De Joint was echter niet die mening toegedaan. «Its leadership entertained deep respect for the learning of the rabbis but could

2 E. Zuroff, The Response of Orthodox Jewry in the Uniled States to the Itolocaust. The Activities of the Vaad ha-IIalzala Rescue Commiltee 1939-1945, New York, 2000, p. 36.

${ }^{3}$ Y. Bauer, American Jewry and the Holocaust. The American Jewish Joint Distribution Committee, 1939-1945, p. 127. 
not see why their lives should take precedence over the lives of others.» ${ }^{4} \mathrm{Op}$ een moment waar het belangrijk was geweest om zoveel mogelijk samen te werken voor het redden van joden over heel Europa, leek de relatie tussen de Joint en de Vaad Hahatzala enkel te verslechten ${ }^{5}$. Vaad Hahatzala doorbrak eveneens het monopolie van de Joint wat geldcollectes betrof. In juni 1946 werd zelfs een speciale organisatie hiervoor in het leven geroepen, Rescue Children, Inc., opgericht door Herbert Tenzer. Deze organisaties waren een doorn in het oog van de Joint. De Joint deed er dan ook alles aan om de initiatiefnemers van dit alles ervan te overtuigen dat er geen nood was aan aparte orthodoxe hulporganisatie, aangezien de Joint orthodoxe joden evengoed steunde als niet-orthodoxe. De onderhandelingen verliepen succesvol voor de Joint.

In mei 1947 keurden de Union of Orthodox Rabbis op een interne vergadering een akkoord goed dat leidde tot de oprichting op 29 juli 1947 van het Jewish Central Orthodox Committee, beter bekend als Central Orthodox Committee, een autonome Amerikaans joodse organisatie voor de heropbouw van het religieus leven van joden in Europa, samengesteld uit vooraanstaande rabbijnen en leken van het orthodoxe Amerikaanse jodendom. Deze organisatie zou de Joint op de noden van religieuze joden in Europa attent maken. De Joint ging recht op het haar voor ogen gestelde doel af. Dat blijkt duidelijk uit de openingsparagraaf van deze overeenkomst : "The American Jewish Joint Distribution Committee has always been deeply interested in promoting the orthodox way of life, as is evidenced by the funds it has expended for the support of orthodox institutions throughout the years of its existence, and particularly during the last two years since the end of the war. To eliminate the confusion which has been created in the American Jewish community by a number of organizations by reason of competitive appeals for support of various religious activities in Europe, and in order that the Joint Distribution Committee may have the benefit of recognized orthodox opinion in the conduct of its work relating to the support of religious activities in the European countries, the Joint Distribution Committee has proposed that a

${ }^{4}$ Ibid., p. 127.

${ }^{5}$ E. Zuroff, op. cil., p. 256. 
central body or committee be organized to represent all elements of orthodoxy in the American Jewish community $\aleph^{6}$.

De bereidheid van de Union of Orthodox Rabbis om op dit voorstel te reageren, was dus al een stap richting centralisatie in Amerika, een basis om verder te werken aan de unificatie van de fondsen inzameling. De tweede en derde paragraaf van deze overeenkomst waren belangrijk in dit verband. In de tweede paragraaf lezen we : « The Joint Distribution Committee will recognize the Jewish Central Orthodox Committee as the sole representative group to whom the various problems of orthodoxreligious rehabilitation in Europe will be referred for consideration in consultation with the respective European local orthodox groups and the JDC representatives, in regard to the financial needs for the establishment and maintenance of orthodox life and institutions in the European countries. " De derde paragraaf luidt : "All financial aid for religious work which may be recommended by the Jewish Central Orthodox Committee and as may be accepted by the Joint Distribution Committee, is to be made as part of the general budget of the Joint Distribution Committee for each country or region. » De Joint stelde zich bijzonder genereus op om dit initiatief te laten slagen en stond in voor de kosten voor de opstart en het eerste werkingsjaar van dit comité. Intussen probeerde het eveneens het actieterrein van de door de Union of Orthodox Rabbis in het leven geroepen Vaad Hahatzala te beperken. Vaad Hahatzala mocht volgens de overeenkomst van 29 juli 1947 enkel deze projecten steunen die geen subsidies van de Joint ontvingen en diende zich daarnaast te beperken tot hulp bij de emigratie van rabbijnen en jeschivastudenten. Daarenboven verbond de Union of Orthodox Rabbis zich ertoe geen aparte inzamelingen meer te organiseren ${ }^{7}$.

Op 1 januari 1948 kwam het tot een akkoord tussen Rescue Children, Inc. (de financieringsorganisatie van de Vaad Hahatzala) en de

\footnotetext{
${ }^{6}$ Archives of the American Jewish Joint Distribution Committee, Jerusalem (verder afgekort als JDC-I), file 178B/179A 3, "Agreement between the American Jewish Joint Distribution Committee and the Union of Orthodox Rabbis of the USA and Canada » [29.07.1947].

${ }^{7}$ " The Union of Orthodox Rabbis agrees to dissociate itself from other fundraising efforts or groups which endeavour to collect funds in this country and Canada for assislance to orlhodox inslitulions, groups and projects which properly come within the purview of the Joint Distribution Commiltee and the Jewish Central Orthodox Committee, whether such activities are carried on directly or indirectly, and to discourage separate appeals for such purposes. "
} 
Joint, waarbij Rescue Children, Inc. haar omhalingsactiviteiten zou stopzetten mits de belofte van de Joint dat deze alle door Rescue Children, Inc. gesteunde projecten zou subsidiëren en wel op zo'n manier dat geen toegevingen werden gedaan op religieus gebied (koosjere homes blijven koosjere homes, de opvoeding van de kinderen blijft een streng orthodoxe, enz. $)^{8}$. Met deze overeenkomst van januari 1948 had de Joint dus het vertrouwen van de Amerikaanse orthodoxie gewonnen en ze moest er nu voor zorgen dit niet te beschamen. We kunnen dus verwachten dat het hoofdbureau van de Joint in New York aanvragen vanuit orthodox joodse hoek steeds ernstig zal genomen hebben en ook daadwerkelijk steun zal verleend hebben als dat binnen de mogelijkheden viel. De Amerikaanse orthodoxie was duidelijk een factor waar ze rekening mee moest houden'. Wel merken we op dat het $J e$ wish Central Orthodox Committee, dat in feite de eerste stap in deze centralisatie betekende, al in 1950 ophield te bestaan.

\section{De lokale situatie in Antwerpen}

Omdat er meer joden in Brussel woonden na de oorlog en misschien ook omdat daar gemakkelijker dan in Antwerpen kon verder gebouwd worden op reeds bestaande structuren, vestigde de Joint haar vertegenwoordigers in de Belgische hoofdstad. Zij koos de hulporganisatie Aide aux Israélites Victimes de la Guerre (AIVG), met hoofdzetel in Brussel als haar Belgische centrale vertegenwoordiger. Deze AIVG was samengesteld uit de verschillende strekkingen van het Belgische jodendom en zeker niet dominant orthodox. De vertegenwoordigers van de Joint in België kwamen er dus niet in een orthodoxe omgeving terecht. De Joint-vertegenwoordiger en de AIVG dienden voor de Joint de Belgische noden in te schatten en de middelen te verdelen. Hun motivatie om een bepaalde aanvraag wel of niet te steunen, was veel meer concreet ingegeven door de situatie in België, dan door de onderhande-

\footnotetext{
${ }^{8}$ Yeshiva University Archives (New York), Collection Maurice Enright, box 1, folder 3, « Agreement between American Jewish Joint Distributions Committee, Inc. and Rescue Children, Inc. 1 January 1948 ».

${ }^{9}$ Dat was een groot verschil ten opzichte van bijvoorbeeld communistische joden die uiteraard geen steun uit Amerikaanse hoek kregen.
} 
lingen in Amerika om bijvoorbeeld Rescue Children, Inc. binnen de grote Joint-structuur in te kapselen.

Belangrijk om vooraf nog te vermelden is de samenwerking tussen de Joint en de Conference on Jewish Material Claims Against Germany (Claims Conference). De Claims Conference kende vanaf 1954 jaarlijks subsidies toe voor hulp aan Holocaustslachtoffers en voor de heropbouw van joods leven in Europa. Claims Conference wenste hiertoe samen te werken met de Joint die intussen al de know-how ter plaatse opgebouwd had. De overeenkomst was dat de Joint-vertegenwoordigers de bij de Claims Conference ingediende projecten ter plaatse zouden onderzoeken en dat de Joint ook mee zou financieren voor de door de Claims Conference gesteunde projecten. Op die manier werden de middelen van beide organisaties optimaal gebruikt. Vanaf 1954 zijn Claims Conference-projecten dus evengoed Joint-projecten. De medewerkers van beide organisaties hebben vlotte en frequente contacten. De samenwerking betekende ook een vermindering van de financiële last voor de Joint, waardoor projecten die voordien weinig kans op steun hadden (vaak culturele, zoals onderwijs), na 1954 wel subsidies toegekend kregen. Deze samenwerking manifesteert zich duidelijk, zij het misschien vooral via de bronvermelding, in dit artikel.

\section{De Antwerpse casus}

\section{De "kinderkwestie"}

De Joint-vertegenwoordigers en de AIVG handelden heel pragmatisch. Dat botste nogal vaak met de overtuigingen van heel religieuze joden. De zogenaamde "kinderkwestie", of alles wat te maken had met het terughalen van joodse kinderen uit een niet-joods milieu, vormde het meest delicate discussieonderwerp uit de naoorlogse periode.

De Joint-vertegenwoordigers waren van mening dat de kinderen die bij niet-joden de oorlog overleefd hadden weliswaar terug moesten gebracht worden naar een joods milieu, maar dat de voorwaarde daartoe wel was dat er voldoende middelen waren om hen op te vangen. Er waren bijna geen joodse pleeggezinnen voor de oorlogswezen en het was niet evident om onmiddellijk voldoende kindertehuizen op te richten. De eerste Joint-vertegenwoordigster voor België na de oorlog, Laura 
Margolis, hechtte veel belang aan het emotionele en materiële welzijn van de kinderen. In haar ogen was het zelfs beter om overlevende kinderen uit de kampen in Duitsland tijdelijk onder te brengen bij katholieke gezinnen dan ze nog een dag langer in de kampen te laten. Zover volgde de Joint haar evenwel niet : het was inderdaad niet nodig om de kinderen overhaast weg te halen van de niet-joodse omgeving waar ze de oorlog overleefd hadden, maar zelf joodse kinderen in een katholieke omgeving onderbrengen, dat was ook weer een stap te ver, dat stond de organisatie niet toe ${ }^{10}$.

Er werden dus systematisch kindertehuizen opgericht en geleidelijk werden joodse kinderen hierin ondergebracht. De politiek van de Joint was zo dat zij één fundamenteel principe hadden, met name dat alle joodse kinderen in een joods milieu moesten terechtkomen ${ }^{11}$. Hoe dit gebeurde en welke opvoeding de kinderen dan wel zouden krijgen (zionistisch, religieus...), dat liet de Joint helemaal over aan de lokale door haar gesubsidieerde comités, in België was dat de AIVG. De AIVG nam de homes van de Vereniging van de Joden in België over en opende geleidelijk aan, voor zover de middelen het toelieten, nieuwe homes ${ }^{12}$. De homes moesten volgens de AIVG de rol van het joodse gezin overnemen, niet alleen in de gezinswarmte, maar ook in de band van de kinderen met het jodendom, zijn tradities en spirituele waarden. Toch werd niet voor een louter joodse opvoeding geopteerd. "Notre éducation dans le Home doit être en même temps juive et universelle, mais en aucun cas elle ne peut signifier nationalisme ou ignorance des valeurs culturelles autres que judaïques. $\aleph^{13}$

Natuurlijk was de Joint mee kop van jut wanneer deelorganisaties of groepen buiten het centraal door de Joint gesubsidieerde comité kritiek hadden op de keuzes die dat lokale comité in dat verband maakte. Vaak waren de Joint-vertegenwoordigers immers ook aanwezig bij vergaderingen van dit lokale comité, zodat zij toch ook hun inspraak

10 Archives of the American Jewish Joint Distribution Committee, New York (verder afgekort als JDC-NY), collection 45/54, file 150, Laura Margolis aan Joe, 09.06.1945.

${ }^{11}$ American Jewish Archives (Cincinnati), World Jewish Congress-files (verder afgekort als AJA,

WJC-files), D78/10, «Conférence de Miss L. Margolis, déléguée du Joint, 19 nov. 1945 ».

12 Ibid.

${ }^{13}$ JDC-NY, file 150, Aide aux Israélites Victimes de la Guerre. Section « Enfance » affiliée à

l'Union « O.S.E. ». « Rapport d'Activité », 31.12.1945. 
hadden in de te nemen beslissingen. Door dit of dat comité precies uit te kiezen als het centrale lokale comité, plaatste de Joint zich ook in zekere zin achter de politiek die dat comité voerde. Voor België was dat lokale comité dus de AIVG. We zullen nog meermaals zien dat de AIVG niet door alle joden in België als representatief werd beschouwd. « The local committee, furnished with funds by the JDC are [sic] composed mainly by half-Jews, and those tolerated by the Gestapo [...] needs the fullblooded Jewish population, who suffered excruciatingly, are being neglected by these [sic] "official committee" " ". Vele joden waren niet opgezet met de Belgische "notabelen" die de leidende functies naar zich toetrokken. Het tolerated by the Gestapo verwijst hoogst waarschijnlijk naar de joden van Belgische nationaliteit (die bescherming genoten, althans voor een zekere tijd) of naar de nog steeds legaal actieve structuren van de joodse gemeenschap in Brussel die tot het einde van de oorlog in de legaliteit waren blijven doorfunctioneren ${ }^{15}$. Bovendien waren zij reeds té geassimileerd om te kunnen spreken voor de hele joodse gemeenschap in België.

Orthodoxe groeperingen in België, en dan vooral in Antwerpen, konden zich absoluut niet in de pragmatische politiek omtrent de kinderkwestie terugvinden. In hun ogen was het ondraaglijk dat joodse kinderen na de bevrijding nog in een niet-joods milieu zouden vertoeven. Middelen of geen middelen, de kinderen moesten stante pede terug gebracht worden. Zij uitten dan ook sterke kritiek op de naar hun mening al te lakse houding van de Joint en de AIVG ${ }^{16}$. De twee groepen die deze kritiek het sterkst onder woorden brachten waren de Antwerpse afdeling van AIVG, de Hulp aan Israëlieten Slachtoffers van de Oorlog (HISO), en het Comité Central Israélite pour la Réorganisation de la Vie Religieuse en Belgique (CCI), een sterk religieuze organisatie met

14 JDC-NY, file 150, Vox Populus (anonieme brief) aan Paul Baerwald (JDC-N Y), 12.10.1945.

${ }^{15}$ R. Van Doorslaer - J.-Ph. Schreiber (ed.), De curatoren van het getto. De Vereniging van de Joden in België lijdens de nazi-bezelling, Tielı, 2004.

${ }^{16}$ De kinderafdeling van de AIVG lag overigens nogal sterk onder vuur van omzeggens alle mogelijke strekkingen binnen het Belgische jodendom. Naast de orthodoxen hadden ook zionisten. communisten en assimilationisten zware kritiek op de werking van dit comité (H. Hellemans, "Zij die verloren zijn, zullen niet vergeten worden" (II Samuel 14: 14). Pogingen tot herinlegratie van de kinderen in de joodse gemeenschap na de Tweede Wereldoorlog. Een ideologisch debat, Universiteit Gent, onuitgegeven licentiaatsverhandeling Geschiedenis, 2002, p. 149 e.v.). 
een erg actieve Antwerpse kern (vandaar ook opgenomen binnen "de Antwerpse casus").

Het geduld van beide organisaties raakte al snel op. Jozef Sterngold, Antwerps verzetsheld en na de oorlog heel actief in de HISO, waarschuwde de Joint-vertegenwoordiging en de AIVG er al op de vergadering van 30 oktober 1945 van dat de gemoederen in Antwerpen met betrekking tot de kinderkwestie opliepen ${ }^{17}$. Veel Antwerpse joden namen het niet dat joodse kinderen nog steeds niet teruggebracht waren naar een joods milieu. Hij raadde de AIVG aan zo snel mogelijk een joodse opvang te voorzien voor al deze kinderen. De reactie van de Joint-vertegenwoordiging en de AIVG op deze waarschuwing bleef echter te lang uit. De HISO alarmeerde begin februari 1946 de hele Joint (tot in de VS) en nog een aantal andere internationale joodse hulporganisaties (British Central Fund, Belgian Jewish Representative Committee in New York en Belgian Jewish Committee te Londen) over de passiviteit van de AIVG in het terugbrengen van de joodse kinderen. Ze dreigde de relatie met het Brusselse hoofdkantoor van de AIVG op te blazen indien niet alle joodse kinderen uit het Antwerpse tegen 31 maart 1946 terug in een joodse omgeving verbleven (voor heel België stelden ze 30 april 1946 als ultimatum) ${ }^{18}$. De zaak werd naar de buitenwereld toe betrekkelijk snel opgelost. De HISO was hiertoe wel min of meer genoodzaakt aangezien de AIVG de Jointwerkingsmiddelen in België verdeelde. Er werd een brief verstuurd waarin stond dat de beheerraad van de HISO niet voltallig achter deze resolutie stond. De kinderkwestie was hoogst waarschijnlijk dé doorslaggevende factor die uiteindelijk leidde tot de splitsing tussen AIVG en $\mathrm{HISO}^{19}$.

Naast kritiek op de traagheid waarmee de joodse kinderen gerecupereerd werden, hadden deze groepen ook meer dan detailopmerkingen op de manier waarop de opvang in de AIVG-tehuizen georganiseerd werd. Drie van de elf op 31 december 1945 bestaande AIVG-homes

\footnotetext{
17 Archives Service Social Juif (SSJ) (Brussel), notulen AIVG, 30.10.1945.

${ }^{18}$ JDC-NY, file 150, HISO aan AIVG, 04.02.1946.

${ }^{19}$ Er werd een brief gestuurd door de AIVG waarin stond dat de resolutie in kwestie niet door het volledige bestuur van de HISO gestemd was en dat de AIVG wel zijn uiterste best deed in de kinderkwestie (JDC-NY, file 150, V. Ansbacher (AIVG) aan JDC-NY, 20.03.1946).
} 
waren orthodoxe tehuizen ${ }^{20}$. De anderen waren dat niet omdat het heel moeilijk was om koosjer vlees te verkrijgen in België. De enige manier om de kinderen voldoende voedsel te geven was via de voedselbonnen ${ }^{21}$. Daarbij werd vermoedelijk wel zoveel mogelijk rekening gehouden met de joodse spijswetten. De organisatie van de AIVGhomes was voor sommigen zelf reden genoeg om financiële hulp via andere kanalen dan de AIVG bij de kinderen te krijgen : « M. Sterngold fait part au Conseil de ce qu'une personne d'Anvers serait désireuse de verser une somme importante pour le Home d'enfants d'Anvers; mais le donateur ne désire pas verser l'argent à l'AIVG, n'étant pas d'accord avec le programme généralement appliqué dans les homes d'enfants de $l^{\prime} A I V G »^{22}$.

Eén van de redenen waarom het Comité central israélite pour la Réorganisation de la Vie religieuse en Belgique (CCI) met de hulp van Vaad Hahatzala zelf homes wou oprichten, was omdat de AIVGweeshuizen in hun ogen a- of zelf anti-religieus waren ${ }^{23}$. In september 1945 richtte het CCI een kinderafdeling op en opende een eerste home in Sint-Mariaburg, Notre Nid ${ }^{24}$. Later volgden nog twee homes, één in Antwerpen en één in Brussel. Volgens Sarah Allard wou het CCI alle joodse wezen in orthodoxe homes onderbrengen, wat volgens haar niet kon omdat niet alle kinderen (of hun vermoedelijk overleden ouders) dat zouden willen ${ }^{25}$. De relatie tussen AIVG en CCI liep niet gemakkelijk omdat er gebrek was aan vertrouwen. Met de oprichting van haar eigen homes trad het CCI ook de eerder gemaakte afspraak van 14 no-

${ }^{20}$ JDC-NY, file 150, Aide aux Israélites Victimes de la Guerre. Section « Enfance » affiliée à I'Union « O.S.E. ». "Rapport d'Activité », 31.12.1945: «Le Ilome d'Auderghem esl de stricle observance. Les Homes de Lasne el de Profondsarl donı l'installalion a élé menée à bien grâce aux fonds mis à notre disposition par le Central British Fund, ont une cuisine koscher et sont à tendance religieuse suivant le vœu émis par les donaleurs. "

${ }^{21}$ JDC-NY, file 150, Beatrice Vulcan (JDC België) aan Robert Pilpel (JDC NY), 21.03.1946.

22 Archives SSJ, notulen AIVG, 03.10.1945.

${ }_{23}$ Yeshiva University Archives, Vaad Hatzala, 1939-1963, 22/9, Vaad Hahatzalah, Belgian Section an die Hijefs, Montreux, Brussel, 31/07/1945.

${ }^{24}$ Daarna werden nog twee homes geopend in Antwerpen in de Lange van Ruusbroecstraat 22 (aan de joodse school Jesode Hatora) en in Brussel het Orphelinat Israélite de Bruxelles. In 1948 sloot het tehuis in Sint-Mariaburg en in 1950 werden de kinderen uit Brussel overgeplaatst naar de home in Antwerpen die intussen verhuisd was naar de Generaal Drubbelstraat. Uit verslag aan Claims Conference van CCI in 1954 (privé-archief P. Kornfeld).

25 Archives SSJ, notulen AIVG, 30.10.1945. 
vember 1944 met de AIVG met de voeten ${ }^{26}$. Toen was immers afgesproken dat het CCI zich uitsluitend zou bezighouden met de heropbouw van het religieuze joodse leven in België, de sociale hulp integraal overlatend aan de AIVG.

De aparte CCI-homes waren niet naar wens van de Joint, noch van de AIVG. Een aantal AIVG-leden hadden zo hun ideeën over de doelstellingen van de "andere organisaties" die voor de opvang van de kinderen wilden zorgen. De ene meende dat ze de kinderen naar Palestina wilden sturen, anderen dan weer dachten dat het ging om een " offensive menée contre nos enfants, par pression et par menaces et que, ces organismes espèrent ainsi alarmer l'opinion juive de l'Amérique [...] si l'on veut réaliser le programme d'autres organismes que le nôtre et placer nos enfants dans leurs homes, il faudrait arriver à la solution que ces organismes mettent à la disposition de notre section de l'Enfance leurs homes, et que l'on s'entende ensuite avec eux pour élaborer un programme commun $\aleph^{27}$. De AIVG-leden spraken over de kinderen in België als "onze kinderen" omdat zij de opvang van de kinderen als een door hun te coördineren zaak beschouwden. De Joint had immers de AIVG uitgekozen als centrale vertegenwoordiger en distributeur van de Jointsteun en was ook deze mening toegedaan : "Miss Vulcan [Jointvertegenwoordigster in België] déclare que le Joint est prêt à aider de toutes les manières la section de l'Enfance [van de AIVG...] Miss Vulcan insiste que l'AIVG n'autorise aucun autre organisme à faire des enquêtes que seule la section de l'Enfance est responsable et qu'elle seule a la charge des enfants ${ }^{28}$. Of zoals Laura Margolis het op een conferentie nog geen maand later zou zeggen : "Nous [de Joint, zowel het hoofdkantoor van de Joint in New York als de Joint-vertegenwoordigers in België] ne nous opposerons jamais à aucun projet qui vise le bien-être des enfants, pour autant que l'AIVG en garde contrôle. ${ }^{29}$

De Joint-vertegenwoordigers stonden inderdaad open voor samenwerkingsakkoorden. In het najaar van 1945 ging de Joint bijvoorbeeld in op een voorstel van Antwerpse rabbijnen die een vijftigtal joodse

\footnotetext{
${ }_{26}^{26}$ JDC-VY, file 149, V. Diamant (CCI) aan Max Gottschalk, 09.04.1945.

${ }^{27}$ Archives SSJ, notulen AIVG, 30.10.1945.

${ }^{28}$ Ibid.

${ }^{29}$ AJ A, WJC-files, D78/10, « Conférence de Miss L. Margolis, déléguée du Joint, 19 nov. 1945 ».
} 
pleeggezinnen in het Antwerpse bereid hadden gevonden om joodse weesjes op te nemen ${ }^{30}$. De Joint-vertegenwoordigers in België reageerden zelfs zo enthousiast dat ze twee dagen later al de eerste vijf kindjes naar Antwerpen stuurden, begeleid door Beatrice Vulcan (Jointvertegenwoordigster). Geen van de vijf aangesproken pleeggezinnen was echter voorbereid op de komst van een extra kind. Er was soms niet eens voldoende slaapruimte voor de kinderen van het gezin zelf. Vulcan keerde dus met de vijf onverrichter zake terug. Voortaan zou een afgevaardigde van de AIVG-kinderafdeling eerst een bezoek brengen aan het kandidaat-pleeggezin om de toestand in het huis te peilen en, indien nodig, zelf bijvoorbeeld een bed laten bezorgen. We horen echter niets meer van deze Antwerpse pleeggezinactie, het plan lijkt uiteindelijk niet uitgevoerd. Het is niet helemaal duidelijk op welke basis de rabbijnen een lijst van 50 gezinnen aan de Joint doorgegeven hadden. We mogen dit initiatief in elk geval beschouwen als een van de typische orthodoxe acties om vaart te brengen in de terugkeer van de kinderen naar een joods milieu, waarbij geloofsargumenten zwaarder doorwogen dan materiële mogelijkheden.

De Joint stond ook open voor een samenwerking met het CCI. De leden van het CCI weigerden echter aan te sluiten bij de kinderafdeling van de AIVG. Zij wensten onafhankelijk te blijven, maar vroegen tegelijkertijd wel een subsidie van de Joint voor het onderhoud van de kinderen in hun homes. De Joint-vertegenwoordigster, Laura Margolis, legde hen uit dat alle subsidies via de AIVG zouden gaan en dat indien ze onafhankelijk wensten te blijven dat er zeker een mogelijkheid was om samen te werken wat de plaatsing van de kinderen betrof, maar dat ze dan wel zelf verantwoordelijk waren voor het onderhoud van de kinderen. Moeilijke onderhandelingen tussen AIVG en CCI leidden in 1945 wel tot de overeenkomst dat kinderen van wie men zeker was dat de ouders streng orthodox waren in CCI-tehuizen zouden ondergebracht worden ${ }^{31}$. Had het aan het CCI en de Antwerpse vertegenwoordigers gelegen, dan was de redenering net andersom en had de afspraak geluid dat alle kinderen in orthodoxe homes ondergebracht werden tenzij men kon aantonen dat de ouders werkelijk areligieus of

${ }^{30}$ Ibid.

${ }^{31}$ JDC-NY, file 150, Laura Margolis (JDC België) aan Moses Leavitt (JDC NY), 18.09.1945. 
vrijdenker waren ${ }^{32}$. Het is overigens niet duidelijk of deze overeenkomst wel ooit echt in werking getreden is. Het trieste getouwtrek om de kinderen Zaffern wijst bijvoorbeeld geenszins die kant uit ${ }^{33}$.

De kritiek van beide kanten bleef. Het CCI stuurde de berichten de wereld in dat de kinderafdeling van AIVG varkensvlees had besteld voor de homes en dat er reuzel geserveerd werd aan de kinderen ${ }^{34}$. Uiteraard bereikten deze berichten via de aangeschreven rabbijnen en orthodoxe personaliteiten ook het hoofdbureau van de Joint in New York dat dan bezorgd informeerde bij haar vertegenwoordigers in België waarop deze berichten berustten. Het antwoord uit Brussel weerlegde de beschuldigingen en kaatste de kritiek minstens even hard terug. Het CCI wantrouwde de Joint en de AIVG en stuurde "spionnen" om overal hun werk te gaan controleren. Het CCI was « an organization of the religious Jews headed by a number of very wilful and uncooperative leaders. These men have refused on numerous occasions to work with various groups in the Belgian community but preferred to hold themselves apart in order to be in a position to criticize the work of the other groups $\aleph^{35}$.

Daarnaast kwam er ook kritiek op de erbarmelijke omstandigheden waarin de kinderen in de CCI-homes leefden. De nota over het bezoek van een vertegenwoordiger van de kinderafdeling van de AIVG sprak over de CCI-home in Sint-Mariaburg in termen als "déplorable ", "le home le plus mal tenu que j'ai visité jusqu'à présent. [...] Il fait lourd et triste. Il n'y a rien d'enfantin dans les chambres. [...] On ne peut pas nettement dire que les enfants sont sales, mais ils sont négligés, certains mal peignés. [...] On ne peut s'empêcher d'être frappé par une impression générale de petit ghetto. [...] J'ai retrouvé plusieurs enfants connus par notre groupe. Ils ont tous l'air beaucoup plus négligé qu'aux places où ils se trouvaient précédemment. [...] Il me semble que cette impression en général défavorable doit nous suffire pour ne plus, pour le moment, caser un seul

\footnotetext{
${ }^{32}$ Archives SSJ, notulen AIVG, 20.11.1945.

${ }^{33}$ JDC-VY, file 150, brief met bijgesloten rapport van Leo Rothschild, directeur CCI aan JointNY, 11.03.1946. Hanne Hellemans bespreekt deze affaire in haar verhandeling (op. cit., p. 157159).

${ }^{31}$ Ibid., Leo Rothschild (directeur CCI) aan Chief Rabbi's Religious Emergency Council (London), 16.01.1946.

${ }^{35}$ Ibid., Beatrice Vulcan (JDC België) aan Robert Pilpel (JDC NY), 21.03.1946.
} 
enfant à ce Home. [...] Les enfants ne sont pas créés pour les Homes, mais les Homes pour les enfants. C'est hélas ce que certains groupements semblent oublier. ${ }^{36}$ Een vernietigend rapport dus, waaruit heel sterk de aversie blijkt van de AIVG ten opzichte van die groepen die de kinderen koste wat het wil wilden terughalen, ook al waren de middelen niet voorhanden. Nu was de verslaggeefster, Ida Sterno, wel een Belgische communiste en dus vanuit haar levensbeschouwelijke overtuiging niet geneigd religieuze initiatieven te steunen ${ }^{37}$.

Maar ook Joint-vertegenwoordigster Beatrice Vulcan had geen goed woord over voor het CCI : «They are a thorn in our sides. [...] I will refuse to give them $[\mathrm{CCI}]$ any money outright since I feel that they have not shown any capabilities in running satisfactory Children's Homes. $1^{38}$ Vulcan informeerde de Joint in New York ervan dat het CCI contact had opgenomen met het American Jewish Committee in Londen om in hun voordeel tussen te komen bij de Joint in New York, in plaats van zelf via het lokale bureau en de vertegenwoordigers in België te handelen. De omweg via het American Jewish Committee - en dus niet rechtstreeks via hun sponsor Vaad Hahatzala - werd gemaakt omdat de verhouding tussen Vaad Hahatzala en de Joint toen niet goed was. Dit deed natuurlijk vragen reizen over de houding van de Joint ten opzichte van orthodoxe kinderen. Die was echter niet eenduidig. Zo lezen we in een telegram van Schwartz: "Have assured Herzog that orthodox children will receive same consideration as all other children. $»^{39}$ Of dit rekening houden betekende met de orthodoxie is niet duidelijk ; als " same consideration $»$ betekende dat evenveel geld vrijgemaakt werd per kind, kwamen de religieuze kinderen er bedrogen bij uit, want alleen al bijvoorbeeld strikt koosjer voedsel en de rabbinale controle daarop voorzien, maakte dat voeding meer kostte dan in een niet strikt religieuze omgeving.

De patstelling was compleet : de AIVG beschouwde zichzelf als dé centrale organisatie om de hele kinderkwestie te coördineren - hierin gesteund en gesterkt door de Joint - het CCI en de HISO hadden daar

36 JDC-I, file178B/179A 3, « Home orthodoxe de St Mariaburg », rapport van Ida Sterno (Section Enfance AIVG) [aan Miss Vulcan, JDC België], 05.11.1945.

${ }^{37}$ H. Hellemans, op. cil., p. 90.

38 JDC-NY, file 150, Beatrice Vulcan (JDC België) aan Moses Leavitt (JDC NY), 19/07/1946.

${ }^{39}$ Ibid., Schwartz aan JDC-Paris, 11.09.1946. 
geen vertrouwen in. De onafhankelijk van de AIVG opgerichte homes waren absoluut niet naar de zin van de AIVG. Het liefst van al zagen zij alle tehuizen gecentraliseerd onder hun hoede. Alle tehuizen zouden fondsen krijgen op voorwaarde dat de AIVG controle kon uitoefenen op het gebruik ervan (« Le Conseil décide que nous ne pouvons pas assumer un engagement financier pour les homes d'un Comité Local, si ce home n'entre pas dans le cadre de notre Section d'Enfance " $)^{40}$. Deze controlevoorwaarde was net waar het schoentje knelde. De aparte weeshuizen wensten niet gesuperviseerd te worden door een in hun ogen in religieus opzicht onbetrouwbare organisatie.

De reeds vermelde, geslaagde besprekingen tussen Rescue Children, Inc. en de Joint hadden echter tot gevolg dat de CCI-tehuizen in principe vanaf februari 1948 door de Joint zouden gesubsidieerd worden ${ }^{11}$. Hoe mooi het in New York ook moge geregeld geweest zijn, in de praktijk vertaalde deze overeenkomst zich toch ietwat minder gunstig voor de lokale orthodoxie. In feite werd het CCI buitenspel gezet. Zo wees Kate Mendel van de Joint er in mei 1948 in haar instructies aan David Goldberg, op dat moment de Joint-vertegenwoordiger voor België, op dat de CCI-homes geïntegreerd dienden te worden in de kinderafdeling van de $\mathrm{AIVG}^{42}$. De overeenkomst zei ook letterlijk «the responsibility for the homes will rest entirely with the local community child-care agency under whose auspices they will come and through whom the subsidies of the Joint Distribution Committee will be received $»^{43}$. Mendel benadrukte dat het religieus toezicht geenszins door de Joint gefinancierd zou worden. Deze kosten, voordien betaald door Rescue Children, Inc.-geld, waren voortaan voor rekening van het CCI zelf. Dat religieuze toezicht was meteen ook het enige waarvoor het CCI nog in het plaatje verscheen. Voor alle overige zorgen zouden de CCI-homes opgenomen worden binnen de kinderafdeling van de AIVG. De overeenkomst vermeldde in verband met het religieuze toezicht dat daar waar het mogelijk was

\footnotetext{
${ }^{40}$ Archives SSJ, notulen AIVG, 03.10.1945.

41 Naast de twee tehuizen van het CCT in België nam de Joint door deze overeenkomst 7 orthodoxe tehuizen in Frankrijk en 1 in Zweden over (JDC-I, file 178B/179A 4, « Agreement between American Jewish Joint Distribution Committee, Inc. and Rescue Children, Inc. »).

42 JDC-I, file 178B/179A 4, Kate Mendel aan David Goldberg (JDC België), 18.05.1948.

${ }^{43}$ Ibid., « Agreement between American Jewish Joint Distribution Committee, Inc. and Rescue Children, Inc. ».
} 
deze tehuizen onder het toezicht van de Poale Agudas Israel zouden geplaatst worden. In eerste instantie waren de Jointvertegenwoordigers zeker van plan om de twee CCI-homes effectief helemaal op te nemen in de AIVG-kinderafdeling ${ }^{41}$. Hierin speelde ook een louter financiële factor; de opname in de kinderafdeling van de AIVG die reeds een hele structuur voor weeshuizen kende, was veel goedkoper dan het onderhouden van een apart comité dat slechts de zorg voor twee tehuizen op zich nam.

De reactie van het CCI, na een onderhoud met Jointvertegenwoordiger David Goldberg, liet niet op zich wachten. Het CCI zond op 23 mei 1948 een telegram en een uitgebreide brief naar het hoofdkantoor van de Joint in New York en een copie van dat alles naar verschillende andere invloedrijke personen binnen en buiten de Joint. De bewoordingen waren dringend en kordaat, de woordenschat lijkt afkomstig uit de oorlogsterminologie : " whole committee present revolted contract concluded joint without our agreement - stop - joint referring newyork instructions requests full surrender homes to aivg full exclusion comite central - stop - our board and board of foundationmembers of these two homes refuse recognize contract concluded in strict contradiction conditions and instructions decided. $1^{45}$ Geenszins zou het CCI "capituleren". Overigens heeft Goldberg het ook bijzonder onhandig verwoord, of overdreef het CCI in haar schrijven aan New York diens bewoordingen. Zij schreven immers als volgt : "We have been informed by Mr. Goldberg that he got instructions from New York saying that our two hostels must be remitted unconditionally and completely to the AIVG, the local child care agency of Joint in Belgium. $»^{46}$ Dat klonk bijzonder drastisch en het was ook helemaal niet volgens de toon van de gesloten overeenkomst. Goldberg zou de rol van het CCI voor de toekomst voorgesteld hebben als zou het enkel nog, niet bindende, « suggestions » mogen doen met betrekking tot religieuze zaken aan de AIVG of de Joint zelf. Deze heftige reactie van het CCI moet de Joint doen beslissen hebben haar eigen vertegenwoordigers verantwoordelijk te maken voor de overname van de CCI-homes en de AIVG hier niet

${ }^{44}$ Ibid., brief s.n. aan Kate Mendel (JDC-NY), 24.05.1948.

${ }^{45}$ Ibid., CCI aan Joint NY, 23.05.1948.

46 Ibid. 
bij te betrekken. De CCI-homes ontvingen hun subsidies rechtstreeks van de Joint-vertegenwoordigers in België en waren ook enkel aan hen verantwoording verschuldigd, zo was ook in eerdere onderhandelingen begin april 1948 tussen de Joint en het CCI afgesproken geweest ${ }^{47}$.

Wanneer in 1950 de Joint haar kantoor in België sloot, kwam het enig overblijvende CCI-weeshuis in Antwerpen alsnog onder AIVGcontrole. Het CCI vroeg duidelijke garanties aan de Joint over het verder zetten van de tot dan toe bestaande subsidiëring, expliciet verwijzend naar het eerder in dit artikel besproken akkoord tussen de Joint en Rescue Children, Inc. van 1948 ${ }^{48}$. Vanaf 1 mei 1950 nam de AIVG de Joint-taak over ${ }^{19}$. Herstructureringen maakten dat het weeshuis in 1958 door HISO, toen reeds onder de naam "Centrale", overgenomen werd ${ }^{50}$. De Joint slaagde er via compromissen en vele besprekingen dus in om de zorg voor de joodse weeskinderen onder haar centrale hoede en controle te brengen ${ }^{51}$.

\section{Joint-steun voor onderwijs}

Omdat het schoolsysteem in België zo georganiseerd was dat het officieel of staatsonderwijs gratis was, leek het de Joint logisch, zeker als er gebrek aan middelen was, dat de joodse kinderen hier naartoe gestuurd werden. Daarnaast achtte de Joint een joodse opvoeding hetzij in godsdienst, Hebreeuws of Jiddisch - belangrijk. Deze kon bij voorkeur georganiseerd worden na de schooluren in joodse "bijscholen". De Joint stelde hiervoor financiële en materiële middelen ter beschikking, bijvoorbeeld door het leveren van gebedenboeken, Hebreeuwse en Jiddische boeken aan alle joodse scholen ${ }^{52}$.

${ }^{47}$ Ibid., brief s.n. aan Kate Mendel (JDC-NY), 24.05.1948.

${ }^{18}$ JDC-I, file 178B/179A 8, brief van CCI aan Kate Mendel (Joint België), 29.03.1950.

${ }^{49}$ Ibid., brief van Kate Mendel (Joint België) aan M. Diamant (CCI), 30.03.1950.

${ }^{50}$ JDC-I, file 53B/54 29.010, jaarverslag 1960, p. 17.

51 Naast de opvang van de weeskinderen waren er ook speciale orthodoxe organisaties die joodse kinderen opspoorden die zich nog in een niet-joodse omgeving bevonden. Ik kan binnen het kader van dit artikel echter de werking van beide organisatie en hun contacten met de Joint niet in detail bespreken, maar vernoemd beide organisaties, de Save-a-Child Foundalion en Children's Salvation, volledigheidshalve wel bij naam. Ik bespreek deze organisaties wel in mijn proefschrift. 52 JDC-NY, file 151 . 
In Antwerpen echter bestonden reeds voor de oorlog twee grote joodse dagscholen met een voltijds seculier en joods curriculum die vrijwel onmiddellijk na de bevrijding heropend werden, Jesode Hatora-Beth Jacob en Tachkemoni. Daarnaast openden verschillende chassidische scholen (cf. infra). We geven in een tabel een overzicht van het aantal leerlingen in alle joodse kleuter- en lagere scholen voor de periode 1945-1960. In het tijdschrift van de Centrale stond in 1959 dat $80 \%$ van de joodse kinderen les volgden op een joodse dagschool ${ }^{53}$. Halverwege de jaren ' 60 spreekt Sylvain Brachfeld over 85 à $90 \%$ van de joodse kinderen die een joodse opvoeding genoten in Antwerpen ${ }^{54}$.

\begin{tabular}{|c|c|c|c|c|c|c|c|c|c|c|c|c|}
\hline \multirow[b]{2}{*}{1945} & \multicolumn{2}{|c|}{ Tachkemoni } & \multicolumn{2}{|c|}{$\begin{array}{c}\text { Jesode Hatora - Beth } \\
\text { Jacob }\end{array}$} & \multicolumn{2}{|c|}{ B'noth Jerusalem } & \multicolumn{2}{|c|}{ Torah Vejira } & \multicolumn{2}{|c|}{ Talmoed Torah (Belz) } & \multicolumn{2}{|c|}{ Totaal } \\
\hline & 114 & $26,00 \%$ & \begin{tabular}{|l}
328 \\
\end{tabular} & $74,00 \%$ & & & & & & & 442 & $100.00 \%$ \\
\hline 1946 & 353 & $49,00 \%$ & 341 & $47,50 \%$ & & & & & 25 & $3,00 \%$ & 719 & $100,00 \%$ \\
\hline 1947 & 387 & $39,50 \%$ & 564 & $57,50 \%$ & & & & & 30 & $3,00 \%$ & 981 & $100.00 \%$ \\
\hline 1948 & 343 & $35,50 \%$ & 580 & $60,50 \%$ & & & & & 38 & $4,00 \%$ & 961 & $100,00 \%$ \\
\hline 1949 & 370 & $37,00 \%$ & 583 & $58,00 \%$ & & & & & 50 & $5,00 \%$ & 1003 & $100,00 \%$ \\
\hline 1950 & 264 & $28,50 \%$ & 600 & $65,00 \%$ & & & & & 60 & $6,50 \%$ & 926 & $100,00 \%$ \\
\hline 1951 & 274 & $33,00 \%$ & 481 & $58,00 \%$ & & & & & 72 & $8,50 \%$ & 827 & $100,00 \%$ \\
\hline 1952 & 249 & $35,50 \%$ & 368 & $52,50 \%$ & & & & & 85 & $12,00 \%$ & 702 & $100.00 \%$ \\
\hline 1953 & 267 & $33,00 \%$ & 448 & $55,00 \%$ & & & & & 97 & $12,00 \%$ & 812 & $100,00 \%$ \\
\hline 1954 & 316 & $35,50 \%$ & 464 & $52,00 \%$ & & & & & 110 & $12,50 \%$ & 890 & $100.00 \%$ \\
\hline 1955 & 277 & $32,50 \%$ & 490 & $57,50 \%$ & & & 9 & $1,00 \%$ & 75 & $9,00 \%$ & 851 & $100,00 \%$ \\
\hline 1956 & 321 & $34,50 \%$ & 527 & $56,50 \%$ & & & & & 83 & $9,00 \%$ & 931 & $100.00 \%$ \\
\hline 1957 & 330 & $31,00 \%$ & 598 & $56,50 \%$ & & & 45 & $4,00 \%$ & 90 & $8,50 \%$ & 1063 & $100.00 \%$ \\
\hline 1958 & 372 & $35,00 \%$ & 601 & $57,00 \%$ & & & & & 85 & $8,00 \%$ & 1058 & $100,00 \%$ \\
\hline 1959 & 367 & $34,50 \%$ & 518 & $49,00 \%$ & & & 77 & $7,00 \%$ & 100 & $9,50 \%$ & 1062 & $100.00 \%$ \\
\hline 1960 & 388 & $32,00 \%$ & 551 & $45,50 \%$ & 62 & $5,00 \%$ & 107 & $9,00 \%$ & 108 & $9,00 \%$ & 1216 & $100,00 \%$ \\
\hline
\end{tabular}

Tabel : aantal leerlingen in de Antwerpse joodse kleuter- en lagere scholen ${ }^{55}$

De scholen vingen ook weeskinderen en kinderen op van gedeporteerden, transitairen, arme en werkloze joodse ouders, wat zwaar woog op de financiële middelen. De schoolbesturen van Jesode Hatora-Beth Jacob en de Tachkemoni hoopten op hulp van de Joint om een deel van de zware kosten op zich te nemen. De Joint ging hier echter niet op in. De vertegenwoordiger van de Joint beschouwde de aanvraag van de orthodoxe school Jesode Hatora als « a Belgium [sic] problem. These children could go to Belgium [sic] public schools and attend comple-

${ }_{53}$ «V Van het Joint-front », Cenirale, JG VII, nr. 26, december 1959, p. 22.

${ }^{54} \mathrm{~S}$. Brachfeld, Het joods onderwijs in Belgie,, Borgerhout-Antwerpen, 1966, p. 82.

${ }^{55}$ S. Brachfeld, Ibid., p. 99 : « 8. Jaarlijkse toestand van het aantal leerlingen van de Antwerpse Israelitische scholen in kleuter- en lager onderwijs. Aantal ingerichte klassen en aantal ingeschreven leerlingen ». De grijs opgevulde vakken wijzen erop dat men niet over de leerlingencijfers beschikt. 
mentary Jewish Schools such as others described in this letter. If the Jewish Community prefers to run this type of all-day Jewish school, I think it is their responsibility to find the funds for it. ${ }^{26}$ Geen geld dus voor joodse dagscholen in Antwerpen, tussenkomsten bij het hoofdbestuur van de Joint in New York ter wille van de twee grote scholen (Jesode Hatora en Tachkemoni) van invloedrijke Antwerpenaars in New York konden niet baten ${ }^{57}$. Het hoofdkantoor informeerde wel via alle tussenniveau's in New York, Parijs en Brussel naar de situatie, maar dit resulteerde niet in subsidies. De erg actieve joodse gemeenschap in Antwerpen had voor de oorlog ook steeds de scholen zelf gesubsidieerd en zou het ook nu zo moeten doen volgens de Joint ${ }^{5}$.

Stilaan veranderde de houding van de Joint echter. De grote joodse dagscholen in Antwerpen werden steeds meer als een uniek fenomeen ervaren. Studies over joods onderwijs in Europa in de jaren 50 vermeldden de Antwerpse scholen als bijzondere centra van joodse opvoeding en cultuur. Mogelijks speelde de overeenkomst van de Joint met Rescue Children, Inc. een rol (cf. supra). "The schools in Antwerp are undoubtedly the best on the Continent and [...] it would be a criminal neglect to allow them to fail in their work so long as there are ways of keeping them going [financieel steunen dus]. $»^{59}$ De Joint leek dus begrepen te hebben dat joden in Antwerpen wel zouden vasthouden aan joodse dagscholen en paste aldus zijn houding aan. Als vanaf 1954 de Claims Conference (cf. supra) een deel van de fondsen mee betaalde, was de financiële druk minder groot en was de Joint bereid de Antwerpse scholen verder mee te steunen in hun ontwikkeling.

Antwerpen kende een aanzienlijke en sterk aangroeiende chassidische gemeenschap. Tijdens onze onderzoeksperiode (1944-1960) maakte zij maximaal $12 \%$ uit van de totale Antwerpse joodse bevol-

56 JDC- VY, file 151, Beatrice Vulcan (JDC België) aan Edward Philipps (JDC NY), 01.04.1947.

${ }^{57}$ JDC-I, file 178B/179A 13, brief Jules Moed en Samuel Brodt aan Joint Distribution Committee, 19.11.1947. Jules Moed, een voormalig Antwerps diamantair die zijn diamantbedrijf naar New York verplaatst had omwille van de oorlog, en van de voormalige opperrabbijn van de Antwerpse Shomre Hadass die omwille van de oorlog ook naar Amerika uitgeweken was.

58 JDC-NY, file 151, « Hebrew Schools in Antwerp ». Kate Mendel (JDC België) aan AJDC-Paris, 15/01/1948; « Hebrew Schools in Antwerp » Herbert Katzki (JDC-Paris) aan Robert Pilpel (JDC-NY), 21.01.1948.

${ }^{59} \mathrm{Ibid}$., Judah J. Shapiro (JDC Paris) aan Henrietta K. Buchman (JDC NY), 13.04.1950. 
king (vandaag is dat naar schatting $25 \%$ ). Zij wensten hun kinderen niet naar één van de reeds bestaande joodse dagscholen te sturen, maar wilden aparte scholen voor hun kinderen om hun helemaal volgens hun geloofsovertuiging op te voeden. " As far as they [de Belzer] are concerned, the Tachkemoni school and the Jesode Hatorah have already introduced certain modern concepts which, as far as they are concerned, are a departure from the spirit of orthodoxy ${ }^{60}$. Bovendien vreesden ze dat hun kinderen door hun specifieke kledij en haartooi op deze scholen uitgelachen zouden worden. De Belzer-chassidiem hadden weinig contact met de rest van de Antwerpse joodse gemeenschap. De Jointvertegenwoordigers die ter plaatse gingen, waren er ook van overtuigd dat deze groep er alles aan zou doen om te verhinderen dat hun kinderen in een andere gemeenschap dan de Belzer zouden integreren. $\mathrm{Zij}$ openden schooltjes die sterk leken op de Oost-Europese chedarim, joodse religieuze lagere scholen ${ }^{61}$.

De discussie over het al dan niet financieren van deze scholen, herhaalde zich - na deze over de joodse dagscholen - nu op een verder niveau. Aanvankelijk ging de Joint ervan uit dat het een tijdelijke vraag zou zijn en was ze daarom van het principe dat deze groepen, zolang ze in Antwerpen verbleven, gebruik moesten maken van de reeds bestaande door de overheid gesteunde joodse dagscholen waar alles reeds voorzien was voor degelijk seculier en joods onderwijs ${ }^{62}$. De Claims Conference en de Joint schreven aan de school dat hun « assistance to the two established Jewish all-day schools in that city [Antwerp] made it unnecessary to assist in the establishment of a third institution. It has been explained that the children presently in your Talmud Thora could

\footnotetext{
${ }^{60}$ CAHJP, CC-files, CG56, Talmud Thora, brief Leonard Seidenman (JDC) aan Herbert Katzki (JDC) " Report on a visit to the Talmud Torah of Antwerp, Cultural application 870 », 10.11.1955.

${ }^{61}$ De chassidische vluchtelingenkinderen werden ook moeilijk aanvaard op de andere joodse scholen : "The children cannot go to the Jesode IIatorah School because they are treated badly as refugee children. They are treated as greenhorns and the group wished to retain its own identity » (CAHJP, CC-files, 6588, Leonard Seidenman (JDC Paris) aan Saul Kagan (Claims Conference NY), 19.10.1956).

${ }^{62}$ CAHJP, CC-files, CC56, Talmud Thora, memorandum van Judah J. Shapiro aan Leonard Seidenman, 17.11.1955.
} 
be placed within the existing Jewish school program in Antwerp ${ }^{63}$. De Antwerpse Belzer gingen hier niet mee akkoord en verweten de Claims Conference (en dus ook de Joint) de verschillende strekkingen binnen het jodendom niet te onderkennen. Ze voegden er een verklaring van rabbijn Chä̈m J. Rottenberg, rabbijn van de Antwerpse strikt orthodoxe joodse gemeente Machsike Hadass, aan toe om te verklaren dat de principes waarop de Talmud Thora steunde verschilden van deze van de twee andere joodse scholen in Antwerpen en dat het dus een noodzaak was deze Talmud Thora te steunen. Dat deze kinderen niet naar de Tachkemoni en de Jesode Hatora konden gaan, was geen verschil tussen bijvoorbeeld liberaal en orthodox of conservatief en orthodox, maar eerder tussen orthodox en "ultra-orthodox" 64 .

In 1954 kwamen er naast de al sedert 1946 functionerende Belzerjongensschool een Belzer-meisjesschool en een nieuwe Satmarjongensschool bij. De oprichting van een Satmar-jongensschool was blijkbaar het gevolg van een conflict tussen Satmar- en Belzerchassidiem in Israël en dat had zijn gevolgen tot in Antwerpen ${ }^{65}$. Voordien gingen de Satmar jongetjes naar de Belzerschool. Het conflict in Israël maakte hier een einde aan. De Joint begreep de beweegredenen om aparte scholen op te richten niet helemaal. Moe Levine van het Joint-kantoor in Genève haalde in een brief van januari 1960 aan Mark Uveeler van de Claims Conference - beide organisaties steunden gemeenschappelijke initiatieven - herinneringen op aan « one of the highlights of the various places we visited together last summer and fall », met name " the little incident at the Chasside Belz school in Antwerp concerning the girls. You admonished the handsome young man with the wonderful black beard about having girls in the school. Why couldn't they go to the Jesode Hatorah school? Why must there be two schools for

${ }^{63}$ Ibid., Talmud Thora, brief van Judah J. Shapiro (Dept. of Cultural \& Educational Reconstruction) aan N. Schapira, Talmud Thora, 16.12.1955.

${ }^{64}$ Ibid., N. Schapira Talmud Thora aan Claims Conference, 17/12/1955 met verklaring van rabbijn Chaïm J. Roltenberg, 26.12.1955.

${ }^{65}$ CAHJP, CC-files, CC58, Talmud Thora, Mark Uveeler aan Rabbi Joseph Lockstein, 03.01.1958. Drie jaar later antwoordden de Satmar op de vraag waarom ze hun school niet konden samensmelten met deze van de Belzer dat zulks niet mogelijk was omdat zij, de Satmar, meer « secular subjects and modern life » worden benadrukken, een aanpak die de Belzer niet begrepen (CAHJP, CC-files, CC59, Talmud Thora, nota Thora Wejirah, Antwerp. M. U. [Marc Uveeler], september 1958). 
girls? He looked at you with a twinkle in his eye, smiled and said :"Listen chavar [sic : chaver, vriend] Uveeler, we raise little boys with payos [slaaplokken]. At the same time we have to raise little girls who will accept little boys with payos, no? The logic was just too much for all of us $\aleph^{66}$.

Toch beklemtoonden alle rapporten de buitengewone situatie van het joods onderwijs in Antwerpen : " Jewish schools of Antwerp, representing all religious tendancies in the community, conservatives, orthodox and extreme orthodox, have an outstanding record in the number of children served in full-time day schools ${ }^{67}$. Hoewel de Joint-vertegenwoordigers geen streng orthodoxe of chassidische joden waren, werden zij toch geraakt door de ijver waarmee deze groeperingen hun specifieke levensstijl uitbouwden. « $I$ [Elijah Bortniker, Joint-vertegenwoordiger] cannot escape some troubled feelings by the need to support such an institution [Talmud Torah Chasidei Belz Antwerp], even though I must objectively admit that we are not to mix into the subtle ideologies of the various groups. At the same time, I was rather impressed by the devotion of these few Hassidim, the Belzer group, to their school and the efforts they make on its behalf ${ }^{68}$. De Joint-mensen voelden zich in een vervelende positie omdat ze enerzijds zelf niet het jodendom voorstonden dat deze joden in Antwerpen uitbouwden, maar dat ze anderzijds nergens een dergelijk dynamisme en motivatie ervoeren als bij deze groepen. In veel verslagen horen we de auteur in kwestie zelf redeneren over welke houding aan te nemen tegenover dit fenomeen. "I actually do not need to describe to you the, say, philosophical foundations of this group [Chasidé Belz]. But I would like to say that although one may or may not agree with the educational aim, and methods used for the achievement of this aim, one must bear in mind that evaluations and opinions with regard to any educational aim and any educational method are essentially completely subjective and relative. As a matter of fact, there is no and cannot be any generally accepted educational aim and method nor can any of these be rejected unless, of course, they are contrary to the continuity and continued existence of the group for which this educational aim has been

${ }^{66}$ CAHJP, CC-files, CC60, Moe Levine (AJDC Geneva) aan Mr. Mark Uveeler (Claims Conference

- New York) «Re : Chasside Belz - Antwerp », 19.01.1960.

${ }_{67}^{6}$ JDC-I, file 53B/54 29.010, jaarverslag 1959, p. 12.

${ }^{68}$ JDC-I, file 178A 20, Chasidei Belz, brief over de Talmud Torah, Antwerp van Elijah Bortniker (JDC Paris) aan Mr. Mark U'veeler (Claims Conference NY), 27.05.1958. 
set $\aleph^{69}$. Vaak raakten Joint-vertegenwoordigers er ter plaatse van overtuigd dat dit één van de enige duidelijke manieren was om het jodendom door te geven aan de volgende generatie. $\mathrm{Zij}$ waren ook bijzonder onder de indruk van de mate waarin zelfs de meest arme chassidiem geld trachten te schenken voor de uitbouw van hun groep (onderwijs, synagoge, ritueel bad...). De vergelijking makend met andere initiatieven, meer liberale of misschien zelfs reform, die de vertegenwoordigers zagen, makkte de auteur van dit verslag het volgende besluit : "I do not want to try to prove here the mistaken thinking, underlining the faulty philosophy of secular plus Jewish education, but if we really and truly believe in our purpose of wanting to reconstruct Jewish life in Europe, we must support rather the indigenous source and strengthen the core than those many streams and currents which have branched off from this core and which ultimately get their impulses and strength from that core. ${ }^{70}$

Zolang ze alleen moest instaan voor de hulp gaf de Joint relatief weinig steun aan de joodse scholen omdat de middelen het niet toestonden. Van zodra de Claims Conference in 1954 een deel van de kosten mee droeg, was er duidelijk meer mogelijk. De beide organisaties steunden samen de twee grote joodse dagscholen Jesode Hatora Beth Jacob en Tachkemoni. Zij konden rekenen op jaarlijkse subsidies (Tachkemoni vanaf 1955). De chassidische initiatieven moesten tot 1958 wachten vooraleer zij een positieve reactie kregen op hun aanvragen. We zien dat de Thora Wejira in 1958 en vooral in 1960 geld ontving, de Talmud Thora kreeg vanaf 1958 tot en met 1960 jaarlijks steun ${ }^{71}$.

Volledigheidshalve voegen we hieraan toe dat de Joint ook twee jeschivot in Antwerpen steunde : de "Kehillat Jacob" (cf. infra) die volledig bestond uit vluchtelingen en overlevenden uit de DP-kampen, en de jeschiva Ets Chaïm te Kapellen die reeds voor de oorlog bestond en tot op vandaag in het Antwerpse gevestigd is. De steun aan deze jeschivot was echter meer een vorm van sociale hulp dan het steunen

\footnotetext{
69 Ibid., Chasidei Belz, brief « My visit to Belgium and Luxemburg » van Education Department (s.n.) aan Mark Uveeler (Claims Conference VY), 15.09.1959.

${ }^{70}$ Ibid.

${ }^{71}$ Jaarverslag Claims Conference. 1954-1960.
} 


\begin{tabular}{|c|c|c|c|c|c|c|c|c|c|}
\hline Jaarverslagen CC & \multicolumn{3}{|c|}{1954} & \multicolumn{3}{|c|}{1955} & \multicolumn{3}{|c|}{1956} \\
\hline & $\begin{array}{c}\text { Bedrag } \\
\text { (in } \$)\end{array}$ & $\%$ & pers/maand & $\begin{array}{c}\text { Bedrag } \\
\text { (in } S)\end{array}$ & $\%$ & pers/maand & $\begin{array}{c}\text { Bedrag } \\
(\text { in } \$)\end{array}$ & $\%$ & pers/maand \\
\hline $\begin{array}{c}\text { Jesode Hatora } \\
\text { Beth Jacob }\end{array}$ & 25.000 & 6,10 & & 12.800 & 2,00 & 655 & 11.500 & $1, \mathbf{8 0}$ & 650 \\
\hline Tachkemoni & & & & 25.000 & 3,90 & 403 & 7.500 & 1,20 & 400 \\
\hline \multicolumn{10}{|l|}{$\begin{array}{c}\text { Thorah Wejirah, } \\
\text { Antwerp }\end{array}$} \\
\hline \multicolumn{10}{|l|}{$\begin{array}{l}\text { Talmud Thora, } \\
\text { Antwerp (Belz) }\end{array}$} \\
\hline $\begin{array}{l}\text { TOTAAL } \\
\text { BELGIË }\end{array}$ & 410.600 & 100 & & 640.807 & 100 & 2.000 & 626.200 & 100 & \\
\hline $\begin{array}{c}\text { Jaarverslagen CC } \\
1954-1960(\text { in } \$)\end{array}$ & \multicolumn{3}{|c|}{1957} & \multicolumn{3}{|c|}{1958} & \multicolumn{3}{|c|}{1959} \\
\hline & $\begin{array}{c}\text { Bedrag } \\
\text { (in } \$)\end{array}$ & $\%$ & pers/maand & $\begin{array}{c}\text { Bedrag } \\
(\text { in } S)\end{array}$ & $\%$ & pers/maand & $\begin{array}{c}\text { Bedrag } \\
(\text { in } \$)\end{array}$ & $\%$ & pers/maand \\
\hline $\begin{array}{c}\text { Jesode Hatora } \\
\text { Beth Jacob }\end{array}$ & 2.000 & $\mathbf{0 , 4 0}$ & 672 & 8.960 & 1,6 & 700 & 11.030 & 2,20 & 738 \\
\hline Tachkemoni & 12.000 & 2,50 & 420 & 7.000 & 1,2 & 496 & 13.000 & 2,60 & 550 \\
\hline $\begin{array}{c}\text { Thorah Wejirah, } \\
\text { Antwerp }\end{array}$ & & & & 1.000 & $\mathbf{0 , 2}$ & & & & \\
\hline $\begin{array}{l}\text { Talmud Thora, } \\
\text { Antwerp (Belz) }\end{array}$ & & & & 5.000 & $\mathbf{0 , 9}$ & 180 & 2.500 & $\mathbf{0 , 5 0}$ & 115 \\
\hline TOTAAL BELGIË & 478.411 & 100 & & 573.042 & 100 & & 498.135 & 100 & \\
\hline \multirow[t]{2}{*}{$\begin{array}{c}\text { Jaarverslagen CC } \\
1954-1960(\text { in } \$)\end{array}$} & \multicolumn{3}{|c|}{1960} & & & & & & \\
\hline & $\begin{array}{l}\text { Bedrag } \\
\text { (in } \$)\end{array}$ & $\%$ & pers/maand & & & & & & \\
\hline $\begin{array}{c}\text { Jesode Hatora } \\
\text { Beth Jacob } \\
\end{array}$ & 24.650 & 4,40 & 800 & & & & & & \\
\hline Tachkemoni & 23.000 & 4,10 & 600 & & & & & & \\
\hline $\begin{array}{c}\text { Thorah Wejirah, } \\
\text { Antwerp }\end{array}$ & 12.500 & 2,20 & 131 & & & & & & \\
\hline $\begin{array}{l}\text { Talmud Thora, } \\
\text { Antwerp (Belz) }\end{array}$ & 2.500 & $\mathbf{0 , 4 0}$ & 118 & & & & & & \\
\hline TOTAAL BELGIË & 562.071 & 100 & & & & & & & \\
\hline
\end{tabular}

van een onderwijssysteem. Ook in de hierboven vermeldde scholen was de steun welgekomen voor het schoolgeld van weeskinderen en kinderen wiens ouders in financiële moeilijkheden zaten. 


\section{Andere steun aan orthodoxie}

Hoewel de Joint weliswaar aandacht schonk aan de orthodoxie, toch lijkt het ons dat noch het hoofdkantoor in New York, noch haar vertegenwoordigers in België die hoofdzakelijk samenwerkten met de AIVG, de complexiteit van de Antwerpse orthodoxie echt begrepen. De vooroorlogse Antwerpse joden hadden het na de bevrijding overigens ook niet altijd zo hoog op met streng orthodoxe en chassidische nieuwkomers. Vóór de oorlog waren minstens vijf chassidische groepen in Antwerpen aanwezig (Wiznitz, Gur, Tschortkow, Satmar en Belz), maar de naoorlogse chassidische populatie groeide sterk aan na de oor$\log ^{72}$. De Antwerpse afdeling van de AIVG, de HISO, wou in de eerste maanden na het einde van de oorlog deze ultra-orthodoxen afremmen. Het fenomeen ontging ook de Joint-vertegenwoordigers in België niet. Beatrice Vulcan schreef einde 1946 aan JDC-NY : «I think you might be interested to know that such tremendous numbers of orthodox Jews in round hats, long beards, and longer coats, have been pouring into Antwerp that the Committee there decided that they would not give relief to anybody who did not wear a conventional fedora [Een zachte vilten hoed afkomstig uit Tirol. Een spits toelopende bol, een gleuf over de lengte van de bol en een middelgrote rand verlenen deze hoed zijn karakteristieke uiterlijk ${ }^{73}$. The Committee provided the fedoras ${ }^{74}$. De Antwerpse afdeling van de AIVG gaf dus enkel steun aan "gewoon religieuze joden" en niet aan de speciaal geklede chassidiem. Deze nieuwkomers vielen enigszins buiten het joodse onderlinge hulpsysteem in Antwerpen. Daardoor kwamen zij in moeilijke omstandigheden aankloppen bij JDC-NY om hun situatie uit te leggen en financiële steun te vragen.

Het verschil met Brussel in deze Antwerpse situatie was dat Antwerpen zonder enige discussie en voor iedereen koosjer voedsel voorzag in haar HISO-volkskeuken. Het Antwerpse comité was zonder meer veel orthodoxer dan het Brusselse. In Brussel, waar in verhouding

${ }^{72} \mathrm{E}$. Schmidt, Geschiedenis van de joden in Antwerpen in woord en beeld, Antwerpen-Rotterdam, 1994, p. 316 ; S.n., Der naye binjen fun Beth Rachel dSatmar in Antverpen. Antwerpen, s.d., p. 10.

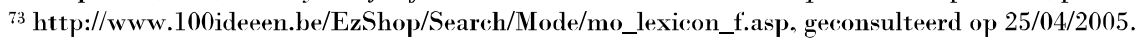

74 JDC-NY, file 149, B. Vulcan aan JDC NY, 06.12.1946. 
minder orthodoxe joden woonden, werden de extra kosten voor koosjer voedsel door de AIVG naar de orthodoxie doorgeschoven ${ }^{75}$. De door de Joint gesubsidieerde AIVG rekende een bepaald bedrag voor voedsel per persoon ongeacht het feit of het over koosjer dan wel niet koosjer voedsel ging. Het gevolg moge wel duidelijk zijn : aangezien koosjer voedsel in vergelijking met niet-koosjer moeilijker te verkrijgen was en bijgevolg duurder, hadden koosjer etende joden in de hoofdstad minder eten dan de anderen, wat scherp protest uitlokte van het Comité central israélite pour la Réorganisation de la Vie religieuse en Belgique (CCI). Hiermee raken we ook meteen hét punt dat de vele discussies met de orthodoxie bepaalde : de specifieke levensstijl - voor voedsel, onderwijs... - van orthodoxe joden was in vele opzichten duurder dan deze van niet-orthodoxe joden. Een systeem waarbij elke joodse persoon evenveel aan steun zou krijgen, resulteerde in een armoedige situatie voor de orthodoxen. Een systeem waarbij elke jood eenzelfde levensstandaard zou hebben, betekende dat in verhouding veel meer geld zou gespendeerd worden aan de orthodoxen. Een moeilijke evenwichtsoefening die meermaals uit balans raakte en nog zou raken.

Rabbijn Rottenberg klaagde in 1946 over het tekort aan steun voor rabbijnen in Antwerpen. Hij telefoneerde de Joint in New York, met als gevolg dat deze uitleg vroegen aan de Joint-vertegenwoordiging in Belgiēंб. We citeren uit dit antwoord : "Now to come to the Rabbis. In October there were only six newly arrived Rabbis in Belgium. These men received considerably more as relief than some of the Rabbis who have been working here have been able to earn. This came about because the Board members were so generous with JDC money. At the end of October, I insisted on knowing how many Rabbis there were to support before allowing any subsidy for November. I had not yet gotten that information when Rabbi Rottenberg telephoned New York, which probably accounts for his phoning. I have now been informed that there are 14 Rabbis plus their families or a total of 40 people. Nobody can give me any assurance that these men are really Rabbis, since there seems to be an understandable reluctance to question them very closely. However, we have agreed to give

75 JDC-NY, file 150, Leo Rothschild, directeur CCI aan Chief Rabbi's Religious Emergency Council (London), 16.01.1946.

${ }^{76}$ JDC-NY, file 149, Henrietta K. Buchman (JDC-NY) aan JDC-België, 15.11.1946. 
them relief on a more generous scale than we use for other relief clients and on a scale which should make it possible to meet their minimum needs. ${ }^{77}$ Over Rottenberg voegde ze er nog aan toe dat hij een onstabiel persoon was en dat de rabbijnen geenszins onder zijn hoede stonden.

Blijkbaar was de houding van de Antwerpse HISO dermate negatief dat wanneer een chassidische groep jeschiva-studenten en hun rabbijnen steun toegezegd kregen van de Joint, zij ervoor kozen om verantwoording verschuldigd te zijn tegenover de AIVG in Brussel ${ }^{78}$. De groep, Kehillat Jacob, was gevestigd in Antwerpen. Als persoon apart, als "transitairen", dienden deze migranten zich elk afzonderlijk tot de HISO te wenden voor steun ${ }^{79}$. De levensomstandigheden van de groep waren echter erbarmelijk. De jongens waren omzeggens allemaal kampoverlevenden. Het voedselrantsoen dat ze toebedeeld kregen in de volkskeuken van de HISO volstond niet. De slaapgelegenheid was bijzonder primitief, de gezondheid van de meesten heel slecht. "These people, however, suffer indescribable poverty. Their faces drawn, they go naked and sleep under conditions that remind one of life in the German camps. ${ }^{80}$ Verschillende alarmerende berichten bereikten het Jointhoofdkantoor in New York. Er was dringend nood aan kleding, medicijnen en voedsel. De Joint-vertegenwoordigers in België zouden niet geïnteresseerd zijn in de jeschiva ${ }^{81}$. Daarom zond rabbijn Grunwald van de jeschiva verschillende telegrammen naar verscheidene religieuze persoonlijkheden in de Verenigde Staten, inclusief naar leden van het Cultureel Comité van de Joint in New York ${ }^{82}$. Van zodra ze echter steun aanvroegen voor de hele groep zou de Joint hun als een groep er-

\footnotetext{
77 Ibid., B. Vulcan aan JDC NY, 06.12.1946.

${ }^{78}$ JDC-I, file 154B 32, program Belgium, AJDC Brussels Miss Kate Mendel aan AJDC Paris European Headquarters Dr. Joseph J. Schwartz, « Closing of JDC Office for Belgium », 14.04.1950.

${ }^{79}$ JDC- VY, file 167, Hirsch Lipschutz aan Tomchey Thora, 11.03.1947.

${ }^{80}$ Ibid., Joseph Greenwald (Yeshivath Kehillath Yaakov) aan Dr. Jung, 27.02.1947 (translation from the Hebrew).

${ }^{81}$ Ibid., Joseph Grunwald (Yeshiva Kehilat Jacob) aan Dr. Jung, 21/04/1947. Deze bewering werd tegengesproken door deze vertegenwoordigers. Beatrice Vulcan schreef : « our relationships with them are quite good » (JDC-NY, file 167, "Your letter nr. 224, Yeshiva Kehillat Jaakov » Beatrice Vulcan (JDC-België) aan JDC New York, 09.07.1947).

${ }^{2}$ Ibid., « Yeshiva Kehilloth Yaakov, Szombathley, Antwerp, Belgium », Edwards Philips (Committee on Cultural Affairs, JDC-NY) aan AJDC-Paris, 18.04.1947.
} 
kennen en één gemeenschappelijk bedrag toegekend krijgen ${ }^{83}$. Normaliter wou de Joint dat de HISO dit dossier behandelde, gezien zij het Antwerpse door de Joint gesteunde comité waren. Kehillat Jacob vreesde echter oneerlijk behandeld te worden door de HISO. De HISO zou volgens hun ook de subsidies stopzetten wanneer de jeschiva ook maar de minste geldinzamelactie zou voeren en er werd gevreesd dat de rapporten die HISO aan de Joint zou leveren over de jeschiva niet met de waarheid zouden overeen komen. De kans op slagen van deze inzamelacties in Antwerpen schatte de Joint ook bijzonder klein, rekening houdende met het fenomeen dat de chassidische nieuwkomers buiten het circuit van de anders heel goed werkende onderlinge hulp binnen de Antwerpse joodse gemeenschap vielen ${ }^{81}$. Kehillat Jacob zou dus Joint-steun krijgen via de Joint-vertegenwoordigers in Brussel $\mathbf{n}$ ook aan hen rapporteren. De meest orthodoxe en chassidische groeperingen, op het CCI - om reeds uitgelegde redenen - na (cf. supra), kozen liever voor de minder religieuze AIVG dan voor de Antwerpse HISO. De AIVG stond immers zo ver van hun handelswijze dat zij vanuit die hoek geen kritiek of controle verwachtten. De HISO - die niet happig was om officieel te maken te hebben met de jeschiva - was daar zeker helemaal mee akkoord. In beide gevallen, dat van de fedora's en dit van de chassidische jeschiva, merken we een sterk negatieve houding van het Antwerpse comité ten opzichte van ultra-orthodoxie en chassidisme. Het vreesde dat het armoedige uiterlijk en de speciale kledij de aandacht zouden trekken en antisemitisme opwekken. Vermoedelijk wilde het comité zich als geïntegreerde burgers in België distantiëren van de in hun ogen archaïsch of vreemd overkomende Oost-Europese schtetl-cultuur.

De nieuwkomers zetten zelf een organisatie op poten om hun belangen te behartigen, de United Refugee Immigration Association of East Europe (URIA) ${ }^{85}$. Deze organisatie, gevestigd in de Terliststraat 35 ,

${ }^{83}$ JDC-NY, file 158, « United Refugee Immigration Association of East Europe in Antwerp » van Melvin S. Goldstein (JDC-Paris) aan JDC-NY, 18.05.1948.

81 JDC-I, file 179B 21-22, brief AJDC Brussels aan AJDC European Headquarters « United

Refugee Immigration Association of East Europe, in Antwerp », 12.05.1948.

${ }^{85}$ Ibid. 
klopte bij de Joint aan voor steun ${ }^{86}$. De Joint verwees hen echter door naar de HISO, waar voor alle joodse transitairen in het Antwerpse hulp voorzien was. Met de onderlinge discussies tussen de beheerraad van de HISO en de URIA liet de Joint zich niet in. De URIA wenste medezeggenschap binnen de HISO. Maar bij de HISO vond men dat de nieuwkomers eerst voldoende tijd in de stad moesten wonen vooraleer zij medezeggenschap zouden krijgen in dergelijke structuren ${ }^{87}$. Er was een duidelijke band tussen deze URIA en de jeschiva Kehillat Jacob. Het hoofd van de jeschiva, rabbijn Greenwald, was eveneens voorzitter van de vluchtelingenorganisatie.

HISO moest naarmate de jaren vorderden steeds meer rekening houden met de toenemende orthodoxie in de Scheldestad. De blijvende en zelfs uitbreidende aantrekkingskracht van Antwerpen op ultraorthodoxe en chassidische joden maakte dat het comité niet blind kon blijven voor de noden van deze mensen. Strekkingen die onmiddellijk na de oorlog nog als te extreem overkwamen, werden stilaan aanvaard- zeker ten overstaan van de nieuwe golf voornamelijk Hongaarse chassidiem in de jaren ' 50 . De Centrale, de rechtsopvolger van de HISO, steunde deze mensen individueel, maar bleef evenwel behoedzaam wat betreft hulp aan een hele organisatie of structuur. Het blijft dus wel zo dat de chassidische groepen zelf hun boontjes doppen en nieuwkomers binnen hun groep opvangen zonder tussenkomst van de Centrale. We illustreren de situatie met een citaat uit het jaarverslag van de Joint uit 1960 : "It is a well known fact which has been commented upon so often that it does not require any special development here, that the City of Antwerp offers an example of a very intensive kind of Jewish life. Particularly in the field of a traditional way of Jewish life as expressed in the practices of the Chassidic groups, Antwerp is one of

86 JDC- VY, file 158, Solomon Tarshansky (Committee on Cultural Affairs (JDC-NY) aan JDCParis, 28/04/1948. Rond Pesach, het joodse paasfeest, melden zij niet voldoende middelen te hebben voor hun paasfeest en vroegen ze een speciale subsidie aan bij de Joint. De Joint kon hen hier niet in volgen omdat er nieuws van HISO was gekomen dat ze voor dit doel een aanzienlijke som geld gecollecteerd hadden in Antwerpen (JDC, 154b, Passover Belgium, brief van Herbert Katzki (secretaris JDC) aan M. Laderman (Central Orthodox Committee), 29.03.1949).

87 JDC-NY, file 158, «United Refugee Immigration Association of East Europe in Antwerp » Melvin S. Goldstein (JDC-Paris) aan JDC-NY, 07/05/1948 ( newly arrived persons in Belgium should not expect to be appointed to the Boards of well established organizations in the country »). 
the two or three places in the world where such families are able to feel relatively at ease. Therefore, for those families who have not wanted to emigrate to Israel and who have not been able to go to America, Antwerp has been a pole of attraction. The Chassidic and other orthodox groups already living in Antwerp, demonstrate a great sense of solidarity towards new arrivals and beyond what this agency [Centrale, gesubsidieerd door Joint] is able to do for them the groups in the community help new arrivals to achieve a relatively high degree of integration in a relatively short time. ${ }^{88} \mathrm{Er}$ waren op die manier in Antwerpen dus een aantal sociale "vangnetten". Allemaal waren zij geïsoleerd van de niet-joodse Antwerpse bevolking met dan intern ook nog aparte onderling diverse groepen.

De fragmentering binnen de Antwerpse orthodoxie was moeilijk te begrijpen voor de Joint. Elke aanvraag voor het restaureren van een door de oorlog vernielde synagoge, voor het aankopen van een nieuw of de uitbreiding van een reeds bestaand gebedshuis werd systematisch afgewezen. De reden hiervoor was voor de Joint nogal duidelijk : er waren al zoveel synagogen en gebedshuizen in Antwerpen, meer dan gelijk waar anders, dus waarom konden de gelovigen niet aansluiten bij één van de vele reeds bestaande ${ }^{99}$ Geld spenderen aan dergelijke vormen van particularisme was volgens de Joint compleet onnodig. Ware de hele religieuze structuur vernietigd geweest zoals in Roemenië bijvoorbeeld, dan zou de Joint wel bij de heropbouw van een minimum aan religieuze infrastructuur (een gebedshuis, mikva en begraafplaats) geholpen hebben ${ }^{90}$. De individualiteit en diversiteit binnen het Antwerpse jodendom kon op dit vlak niet op Amerikaanse steun rekenen.

88 JDC-I, file 53B/54 29.010, jaarverslag 1960, p. 18.

${ }^{89}$ " This is clearly nol a case where the community has no place of worship at its disposal. » (CAHJP, CC-files, CC56, Synagogue Shomre Hadas, « Application 753 - Rebuilding of the Synagogue of Shomre-Hadass (Jewish Community) Antwerp » van Saul Kagan (Claims Conference) aan Herbert Katzki (JDC Paris), 09.11.1955) ; « The Conference advise the applicant that it appreciates its desire to have more adequate synagogue facilities for its members but that in view of the fact that the Conference is aware that the city of Antwerp has sufficient synagogue facilities to meet the needs of the population and because of the Conference's limiled budgel and its urgent high priority welfare needs elsewhere, it is unable to give favorable consideration to this request » (CAHJP, CC-files, CC57, Tifereth Israel, « Preliminary recapitulation »).

${ }^{0}$ Y. Bauer, Out of the Ashes..., p. 151 (Roemenië : « But apart from the 'reconstruction' efforl, or rather as a part of it, JDC paid special attention to the religious and cultural needs of the communities. In the destroyed communities of Northern Transylvania, JDC insisted on unifying religious service for areas and places where the Jewish population simply no longer existed - over the vocal protest of the 
De uitbouw van specifieke faciliteiten zoals een joods zwembad en een joodse kraamkliniek werden niet gesteund, onder meer omdat het volgens de Joint om al te particuliere noden of gebruik zou gaan ${ }^{91}$. Daarmee bedoelen we dat een joods zwembad bijvoorbeeld zou uitgebaat worden volgens de regels van de groep die het bouwde en als dusdanig niet voor alle joden van Antwerpen toegankelijk zou zijn. Zwemmen was overigens belangrijk voor religieuze joden omdat in de Talmoed geschreven staat dat het de verantwoordelijkheid is van de vader om zijn zoon te leren zwemmen ${ }^{92}$. Een joodse kraamkliniek leek dan weer een te grote kost voor het aantal joodse geboortes, rekening houdende met het feit dat in Antwerpen voldoende, zij het dan nietjoodse, voorzieningen waren. Deze voorzieningen zijn - in tegenstelling tot vele religieuze projecten (cf. infra) - dan ook tot op vandaag niet uitgevoerd. Projecten "which give them a ticket of admission to heaven " werden veel genereuzer gesteund dan eerder seculiere ${ }^{93}$. Dat blijkt ook duidelijk als we kijken naar het aantal gebedshuizen in Antwerpen. Ondanks het feit dat de Joint hiervoor geen (of indien in combinatie met een andere voorziening slechts gedeeltelijke) steun voor gaf, waren er in juli 1958 reeds 14 gebedshuizen in gebruik in de stad, een spectaculaire groei ten opzichte van één niet verwoeste synagoge, de Eisenmansynagoge, bij de bevrijding ${ }^{94}$. Vijf van deze 14 gebedshuizen waren van chassidische groepen (Wischnitz, Gur, Belz, Satmar en Tschortkow/Czortkow). Alle vijf hadden ze ook voor de oorlog reeds gebedshuizen in Antwerpen, wat er nog maar eens op wijst dat de

religious funclionaries of the region. But there and elsewhere, wherever possible, synagogues and ritual baths were reslored, places of religious instruclion re-eslablished, and cemeleries repaired. This was done in 71 communities. Psychologically, this was most certainly part of the reconstruction effort »).

${ }^{91}$ JDC-I, file 53B/54 29.010, Jaarverslag 1960, p. 16.

${ }_{92} \mathrm{Y}$. Eliach, There once was a world. A nine-hundred-year chronicle of the shletl of Eishyshok, Boston-New York-Toronto-London, 1998, p. 163.

93 JDC-I, file 53B/54 25.046, Field report - visit to Antwerp Martin Greenberg, 25.11.1958.

94 JDC-I, file 178A 33, Antwerp general, brief Machsike Hadass Antwerpen aan Ph. Vecht (B'nai B'rith Antwerpen), 03/07/1958. Tien van de veertien waren verbonden aan de Machsike Hadass (de grote synagoge van de Oostenstraat, het kleine gebedshuis in datzelfde gebouw, de Eisenmansynagoge en de gebedshuizen van Wischnitz, Gur, Belz, Satmar, Tschortkow, Agudath Israel en dat van de Sterreborgstraat. De andere vier waren de synagoge van de Vanden Nestlei, de Terslist- en de Bouwmeestersstraat, alle drie van Shomre Hadass en de synagoge van Portugese ritus in de Hoveniersstraat. 
komst van chassidiem naar de Scheldestad niet als een naoorlogs fenomeen kan of mag beschouwd worden ${ }^{95}$.

Hoewel het principe van de Joint was om nationaal één centraal lokaal comité te steunen en ondanks het feit dat dit principe in België door de afscheiding van Antwerpen reeds tenietgedaan was, zien we dat de erg specifiek samengestelde joodse gemeenschap van Antwerpen toch tot verdere versnippering van de hulp leidde. De onaflatende druk van de bijzonder dynamische chassidische groepen, vooral Satmar en Belz, resulteerde aan het eind van de jaren ' 50 in afzonderlijke steun ${ }^{96}$. We zagen dit reeds duidelijk voor wat bijvoorbeeld de Belzerschool betreft.

Mede door de akkoorden van de Joint met de Amerikaanse orthodoxie en ook omdat ze uiteindelijk zichzelf al van in het begin tot doel gesteld hadden de noden van alle joden met een zo groot mogelijke neutraliteit te behandelen, steunde de Joint samen met de Claims Conference vanaf halverwege de jaren '50 een aanzienlijk aantal initiatieven uit chassidische hoek. Zij deed dit wel niet zonder enige voorwaarden te stellen. Als zomerkampen van de Satmar subsidies kregen, moesten de Satmar ook Belzer jongetjes laten meegaan én diende er ook werk gemaakt te worden van zomerkampen voor de meisjes die tot dan toe gewoonweg niet bestonden ${ }^{97}$. In de mate van het mogelijke dienden de gesteunde projecten zoveel mogelijk mensen ten goede te komen. Het was echter voor de Joint ook wel duidelijk dat de chassidische projecten steeds maar een beperkte groep bereikten, maar de nood bij deze gemeenschap was dermate groot, dat dit laatste argument het pleit won.

\footnotetext{
${ }^{95}$ E. Schmidt, Geschiedenis..., p. 316 ; JDC-I, file178A 2, brief Rabbi Chaim Mandel, voorzitter Synagogue beth-hamidrash "Chasidei Gur" aan Claims Conference, 27.06 .1962 ; JDC-I, file 178 A 4, brief David Pruver, voorzitter, en Jacob Brenig, ondervoorzitter, Synagogue Klaus Czortkow aan L. Seidenman (country director for Benelux AJDC), 13/12/1961; JDC-I, file 178 A 9, brief Sulem Scharf Rosenberg, voorzitter, en Fischel Lajos Dick, secretaris, Synagoog Chaside Wiznitz aan Claims Conference, 21/06/1960 ; S.n., Der naye binjen fun Beth Rachel dSalmar in Antverpen. Antwerpen, s.d., p. 10.

${ }^{96}$ JDC-I, file 53B/54 29.010, jaarverslag 1959, p. 12 ; jaarverslag 1960, p. 22.

${ }_{97}$ JDC-I, file 178A 17, Sidney Shapiro aan Mr. Louis Kraft (AJDG Geneva) « Preliminary Report on visit to Torah Wejirah Summer Camp in connection with Claims Conference Application », 03.09.1959; « Recommendation on Application of Torah Wejirah, Antwerp, ref. 4032, [1960]».
} 
Deze zomerkampen werden als een terechte en specifiek voor deze groeperingen aangevoelde noodzaak ervaren door de Amerikaanse hulporganisatie ${ }^{98}$. Een eerste argument was dat de studies terplekke in Antwerpen uitwezen dat veel chassidische gezinnen eenvoudigweg de middelen niet hadden om hun kinderen op vakantie te laten gaan, of met andere woorden, om deze kinderen even uit de stad weg te halen. De rijkere ouders zonden hun kinderen naar zomerpensions in Zwitserland of Engeland, de rest naar het door de Antwerpse Satmar ingerichte Thora Vejirah-zomerkamp, maar de overgrote meerderheid had zelfs daarvoor de middelen niet en hield de kinderen de hele zomer thuis in Antwerpen. Joint-vertegenwoordigers stelden vast dat $60 \%$ van de Belzer en Satmar, de twee grootste chassidische groepen in Antwerpen tijdens onze onderzoeksperiode, extreem arm was. $\mathrm{Zij}$ hadden het in hun rapporten over slechte wooncondities, slechte medische verzorging (veel TBC) en voedseltekort. Vooral het cultuspersoneel, de shochet (ritueel slachter) en mashgiach (toezichter op de kasjroet) bijvoorbeeld, waren van de armsten. Een tweede argument om deze kinderen te steunen was dat zij door hun specifieke joodse opvoeding geen kans hadden om mee te kunnen gaan met andere kampen. Debby M. verwoordde het in haar nota om het project te steunen : « They have a large number of poor children (big families), who, because of their payoth and special dress as well as their religious requirements, cannot go to any camp other than the one created by their own group with their own conditions. ${ }^{99}$ Daaronder was bijvoorbeeld de voorwaarde dat de kampen niet gemengd zouden zijn.

\section{Conclusie}

Uit de besprekingen en akkoorden van het bestuur van de Joint met orthodoxe organisatie in de VS mochten we verwachten dat de Joint zou openstaan voor initiatieven uit orthodoxe hoek. De Joint gaf inderdaad steun aan de Antwerpse orthodoxie. Als de plaatselijke Joint-afgevaardigden of de AIVG deze hulp niet spontaan boden, wis-

${ }_{98}$ Ibid., Interview with Mr. Rosenberg, Mr. Hutterer, Thora Vejirah (Satomara), Antwerp, 12.05.1958

${ }^{99}$ Ibid., nota Debby M, 11.09.1958. 
ten de verschillende strekkingen van de Antwerpse orthodoxie de juiste personen aan te spreken in de VS die dan op hun beurt het hoofdkantoor in New York op de hoogte brachten waarop de hulp uiteindelijk vaak verkregen werd.

In tijden van zware nood, zoals onmiddellijk na de bevrijding, moesten specifieke vragen echter wachten en dat gold voor elk van hen, religieus of niet-religieus. De prioriteiten van de Joint waren om de meest dringende noden eerst te ledigen. Indien er middelen overbleven voor minder urgente zaken (en zeker vanaf 1954 wanneer de Claims Conference-middelen de projecten mee financierden), stond de Joint open voor elk initiatief. De voor de Joint vaak moeilijk te vatten gediversifieerde orthodoxie in Antwerpen werd gehoord en geholpen daar waar zij er de Joint van kon overtuigen dat een aantal aanzienlijk joden er voordeel bij zouden hebben. De pragmatische politiek van de Joint botste soms met de religieuze overtuiging van de aanvragende instanties. De Joint moest bij het financieren van projecten steeds schipperen en zoeken welke instantie als controleorgaan aan te stellen. Dat was gezien de sterke verdeeldheid en de houding van de AIVG en de HISO/Centrale niet eenvoudig. We kunnen de houding van de Joint ten opzichte van de orthodoxie voor de Antwerpse casus samenvatten als "pragmatisch positief". 